\title{
RISIKO OPERASIONAL \\ PADA BAGIAN MONEY MARKET TREASURY GROUP DI PT. BANK MNC INTERNASIONAL, TBK JAKARTA
}

\author{
Saur Costanius Simamora \\ Program Studi Manajemen \\ Fakultas Ekonomi \\ Universitas Dirgantara Marsekal Suryadarma \\ Email: saurcsimamora@gmail.com
}

\begin{abstract}
Abstrak
Setiap bank di dalam lingkungan industri perbankan akan menghadapi risiko. Risiko operasional telah menjadi bagian dalam perhatian Bank Indonesia sebagai regulator perbankan di Indonesia. Bank Indonesia mendorong bank-bank di Indonesia agar dapat melakukan tata kelola perusahaan dan manajemen risiko yang baik. Hal ini tidak terkecuali pada bagian pasar uang di Divisi Treasuri. Penelitian ini hendak mengidentifikasi bagaimana profil risiko-risiko operasional apa yang dihadapi Treasuri bagian pasar uang (money market). Diharapkan perusahaan kedepannya dapat melakukan pemetaan, kemudian membuat respon penanganan yang tepat serta pengendalian atas profil risikorisiko yang dihadapinya disertai dengan sistem pelaporan yang akurat. Hasil identifikasi profil risiko pada bagian pasar uang terdapat 40 risiko yang akan dihadapi oleh PT. Bank MNC Internasional, Tbk. Risiko-risiko operasional yang dihadapi oleh bagian pasar uang tersebut dapat berasal dari internal maupun eksternal. Penyebab risiko operasional yang berasal dari internal terdapat 29 risiko, sedangkan penyebab risiko operasional yang berasal dari eksternal terdapat 11 risiko. Dampak risiko operasional pada bagian pasar uang (money market) dengan menggunakan metode Standardized Approach (SA) sebesar Rp. 29,055,106,469.20. Hal ini menggambarkan modal risiko operasional yang harus dihadapi oleh PT. Bank MNC Internasional, Tbk. PT. Bank MNC Internasional, Tbk hendaknya menerapkan enterprise risk management terintegrasi untuk keseluruhan perusahaan, dimana didalamnya terdapat Divisi Treasuri. Hal ini diawali dengan membuat sistem dan mengumpulkan data-data historis di perusahaan mengenai risiko-risiko yang telah terjadi agar dapat disimpan dengan baik.
\end{abstract}

Kata kunci:

Risk, Operational Risk, Treasury, Pasar Uang 


\section{Abstract}

Every bank within the banking industry will take on risks. Operational risk has been a part of Bank Indonesia's concern as national bank regulator in Indonesia. Bank Indonesia encourages every bank to carry out good corporate governance and risk management. This also not limited to the money market in the Tresury Division. This study will (attempt to) elaborate and identify operational risk profiles faced by the the money market in the treasury division; in the hopes that companies will have the tools to plan and establish a correct response to contain various risk profiles that they encounter, along with a detailed and accurate information report. According to the risk profile identification, PT. Bank MNC International will encounter about forty risks. These money market operational risks can come from both internal and external source. Internal contribute about twenty nine risks, where external provides eleven. The impact of operational risks on money market department using the Standardized Approach (SA) Rp 29.055.106.469,20. This illustrates the operational risk capital that must be faced by PT. MNC Bank International, Tbk.It is believed that PT. Bank MNC Internasional, Tbk ought to apply an integrated enterprise risk management for all the branch in the company. The first important step is making a system and by collecting and storing accurate historical risk datas that the company have encountered before.

Keywords:

Risk, Operational Risk, Treasury, Money Market. 


\section{PENDAHULUAN}

\subsection{Latar Belakang}

Perkembangan dunia perbankan yang pesat disertai dengan semakin meningkatnya kompleksitas aktivitas perbankan semakin mempertegas betapa pentingnya tata kelola perusahaan yang sehat (good corporate governance). Hal ini dapat dilihat dari peraturan-peraturan Bank Indonesia dan Otoritas Jasa Keuangan (OJK) yang mendorong agar bank-bank melakukan tata kelola perusahaan dan manajemen risiko yang baik.

Penerapan Peraturan Bank Indonesia No. 5/8/PBI/2003 semakin memperjelas tentang pelaksanaan proses pengendalian risiko untuk mengelola risiko tertentu yang dapat membahayakan kelangsungan usaha bank. Pada Basel II juga mewajibkan bank untuk memiliki rencana keberlangsungan usaha dan rencana darurat (business continuity plans dan contingency plans) untuk memastikan kemampuannya, agar dapat tetap beroperasi dan membatasi dampak kerugian jika terjadi suatu gangguan terhadap aktivitas bisnis baik secara sistematik maupun tidak sistematik.

PT. Bank MNC Internasional, Tbk sebagai bagian dari industri perbankan juga diwajibkan untuk menyesuaikan diri terhadap perubahan-perubahan yang terjadi di lingkungan industri perbankan. Dengan tingkat persaingan industri perbankan yang semakin ketat dan pengaruh dari gejolak pasar semakin kuat baik dalam maupun luar negeri, maka jelas mendorong pihak manajemen bank untuk mengelola risikorisiko yang kemungkinan timbul di kemudian harinya.

Dalam beberapa tahun ini peran Treasuri di Bank MNC Internasional, Tbk menunjukkan peningkatan peran yang cukup signifikan khususnya dalam kontribusi terhadap penerimaan Bank MNC Internasional, Tbk. Divisi Treasuri sebagai 
profit center semakin dituntut memelihara profitabilitas perseroan. Di lain pihak fungsi treasuri juga berperan dalam pengelolaan risiko, khususnya risiko nilai tukar, likuiditas, operasional dan risiko tingkat bunga juga akan semakin berat seiring dengan kondisi nilai tukar dan makro ekonomi yang masih sangat fluktuatif.

Divisi Treasuri seumpama jantungnya bank sebagai pusat pengelolaan dana (in flow dan outflow) dan kegiatan investasi bank. Menurut Riyadi (2006), Divisi Treasuri bertanggung jawab dalam pengelolaan likuiditas optimal agar tidak terjadi over liquid yang mengakibatkan idle funds bank dan menjaga kepercayaan masyarakat terhadap operasional bank.

Salah satu bagian dari Treasuri yang menangani pasar uang adalah money market department. Pelaku dari pasar uang di Treasuri adalah money market dealer. Nilai yang ditransaksikan setiap harinya volumenya bisa mencapai ratusan juta, milyaran bahkan trilyunan. Oleh sebab itulah diperlukan manajemen risiko menjadi suatu hal yang sangat diperlukan. Jika risiko operasional pada bagian money market tidak dimanajemen dengan baik, maka dapat menimbulkan risiko dampak jangka pendek maupun jangka panjang bagi bank itu sendiri di kemudian hari. Dampak secara pendek adalah kerugian yang langsung diderita oleh bank dalam pengelolaan dananya, sedangkan secara jangka panjang dapat mengakibatkan bank berhenti secara operasional. Hingga saat ini belum ada penelitian manajemen risiko yang membahas risiko operasional Treasury bagian pasar uang (money market).

\subsection{Perumusan Masalah}

Kegiatan pada Divisi Treasuri di bagian pasar uang (money market) juga mengandung risiko yang mengancam baik secara jangka pendek maupun jangka panjang. Oleh sebab itu maka dapat 
dirumuskan permasalahan yang diteliti antara lain:

1.Bagaimana profil risiko-risiko operasional yang dihadapi Treasuri bagian pasar uang (money market) di PT. Bank MNC Internasional, Tbk

2. Seberapa besar dampak risiko operasional Treasuri yang dihadapi oleh PT. Bank MNC Internasional, Tbk?

\subsection{Tujuan Penelitian}

Tujuan penulisan ini adalah:

1.Mengetahui profil risiko operasional yang dihadapi Treasuri bagian pasar uang (money market) di PT. Bank MNC Internasional, Tbk.

2.Mengetahui dampak risiko operasional di Treasuri bagian pasar uang (money market) di PT. Bank MNC Internasional, Tbk.

\subsection{Manfaat Penelitian}

Diharapkan dapat menjadi bahan masukan bagi perusahaan dalam hal manajemen risiko perusahaan, terutama Divisi Treasuri di PT. Bank MNC Internasional, Tbk untuk mengetahui profil risiko yang akan dihadapi pada setiap transaksi atau kegiatan yang dilakukan sehingga perusahaan kedepannya dapat melakukan respon penanganan yang tepat serta pengendalian atas risiko-risiko yang dihadapinya.

\section{TINJAUAN PUSTAKA}

\subsection{Pasar Uang (Money Market)}

\subsubsection{Pengertian}

Pasar uang (money market) merupakan pasar yang menyediakan sarana pengalokasian dan pinjaman jangka pendek. Jangka waktu surat berharga yang diperjualbelikan biasanya kurang dari satu 
tahun. Karena itu pasar uang merupakan pasar likuiditas primer (Kasmir (2012).

\subsubsection{Fungsi Pasar Uang}

Pasar uang pada prinsipnya merupakan sarana alternatif bagi lembagalembaga keuangan, perusahaan-perusahaan non keuangan, dan peserta-peserta lainnya baik dalam memenuhi kebutuhan dana jangka pendeknya maupun dalam rangka melakukan penempatan dana atas kelebihan likuiditasnya (Kasmir, 2012).

\subsubsection{Instrumen Pasar Uang}

Instrumen atau surat-surat berharga yang diperjual belikan di pasar uang ada beberapa macam, yaitu (Kasmir, 2012):

\section{Treasury Bills}

Treasury Bills (T-Bills), merupakan instrumen hutang yang diterbitkan oleh pemerintah atau Bank Sentral (di Amerika Serikat) atas tunjuk dengan jumlah tertentu yang akan dibayarkan kepada pemegang pada tanggal yang telah ditetapkan. T-Bills tidak memberikan bunga secara langsung tetapi dijual atas dasar diskonto, dengan jumlah diskonto ditetapkan melalui proses pelelangan. T-Bills tidak dimanfaatkan sebagai sarana investasi bagi lembaga keuangan maupun perusahaan non keuangan yang memiliki kelebihan dana. Dengan penempatan kelebihan dana tersebut di samping memperoleh penghasilan (bunga) juga sebagai cadangan likuiditas. Sebagai sarana investasi instrumen pasar uang ini mempunyai berbagai kelebihan, yaitu:

a. Tidak beresiko karena diterbitkan oleh lembaga pemerintah (Bank Sentral).

b.Mempunyai pasar sekunder sehingga mudah diperjualbelikan.

c. Kemungkinan terjadi kerugian apabila investor menjual surat berharga ini untuk memenuhi kebutuhan likuiditasnya adalah sangat kecil. 
Perusahaan atau lembaga yang menjadi investor utama dalam T-Bills ini antara lain Bank Sentral, bank-bank umum, mutual funds, BUMN, lembaga-lembaga keuangan non bank, perusahaanperusahaan, dan badan pemerintah negara lain, dan individu.

\section{Commercial Paper}

Commercial Paper (CP) merupakan promes yang tidak disertai dengan jaminan, yang diterbitkan oleh perusahaan / bank untuk mendapatkan dana jangka pendek. CP dijual kepada investor dalam pasar uang. Dengan demikian CP pada dasarnya merupakan promes di mana penerbit berjanji akan membayar sejumlah tertentu uang pada saat $\mathrm{CP}$ jatuh tempo. Jangka waktu CP ini berkisar mulai dari beberapa hari sampai 270 hari.

Penjualan CP pada umumnya dengan sistem diskonto, namun beberapa diantaranya menggunakan bunga. Penerbitan CP tidak perlu menggunakan penjamin (underwriter) emisi, tetapi beberapa penerbit karena alasan tertentu menggunakan arranger dalam penerbitannya.

Arranger ini pada umumnya merupakan bank-bank umum yang berfungsi sebagai perantara antara pemodal dan penerbit, namun mereka tidak tidak bertanggung jawab atas terjual atau tidak terjualnya $\mathrm{CP}$ yang diterbitkan.

\section{Negotiable Certificate of Deposit}

Negotiable Certificate of Deposit (NCD) atau sertifikat deposito merupakan instrumen yang diterbitkan oleh suatu bank atas unjuk dan dinyatakan dalam suatu jumlah, jangka waktu dan tingkat bunga tertentu. Sertifikat deposito diterbitkan oleh bank-bank umum atas dasar diskonto dengan nilai nominal sekurang-kurangnya Rp. 1 juta dan jangka waktu 30 hari sampai dengan 1 tahun.

Pencairan sertifikat deposito dapat dilakukan setelah tanggal jatuh tempo, 
tetapi apabila pemegang instrumen tersebut membutuhkan dana sebelum jatuh tempo maka mereka dapat menjualnya kepada lembaga keuangan atau kepada investor lainnya. Di samping itu, deposito berjangka selalu diterbitkan dengan atas nama sementara $\mathrm{CD}$ atas unjuk.

\section{Banker's Acceptance}

Banker's Acceptance (BA) merupakan wesel bank yang ditarik oleh seorang eksportir atau importir atas suatu bank untuk membayar sejumlah barang atau untuk membeli valuta asing yang diberi tanda "accepted" apabila bank menyetujui wesel tersebut, dan dapat diperjualbelikan di pasar uang sebagai salah satu sumber pendanaan jangka pendek.

BA merupakan instrumen jangka pendek yang dapat dipindahtangankan. BA pada dasarnya memberikan alternatif untuk mendapatkan kredit pada saat barangbarang yang diekspor dikapalkan untuk segera dikirimkan ke luar negeri. BA pada umumnya digunakan pada proses L/C dalam perdagangan luar negeri. Jangka waktu jatuh tempo BA berkisar antara 30 hari sampai 180 hari.

\section{Bill of Exchange}

Bill of exchange atau wesel adalah suatu perintah tertulis tak bersyarat yang ditujukan oleh seseorang kepada pihak lainnya untuk membayar sejumlah uang pada saat diperlihatkan atau pada tanggal tertentu kepada penarik atau order atau pembawa. Surat wesel harus berisikan halhal sebagai berikut, dalam kaitannya dengan penarikan wesel ini:

a.Perintah tak bersyarat untuk membayar sejumlah uang tertentu.

b. Nama orang yang yang harus membayar (tertarik atau pembayar).

c. Penetapan hari bayarnya.

d.Penetapan tempat di mana pembayaran harus dilakukan.

e. Nama orang atau pihak lain yang ditunjuk untuk dilakukan pembayaran. 
f. Tanggal dan tempat surat wesel ditarik. g.Tanda tangan orang yang mengeluarkannya (penarik). Jangka waktu jatuh tempo wesel ini umumnya berkisar 6 hari sampai 180 hari.

\section{Repurchase Agreement (Repo)}

Repo merupakan transaksi jual beli surat berharga disertai dengan perjanjian bahwa penjual akan membeli kembali surat-surat berharga yang telah dijual tersebut pada tanggal dan dengan harga yang telah ditetapkan lebih dahulu. Surat berharga yang sering digunakan untuk transaksi Repo adalah surat berharga yang dapat diperjualbelikan secara diskonto misalnya SBI, SPBU, CD dan T-Bills.

7. Sertifikat Bank Indonesia (SBI)

SBI pada dasarnya merupakan surat berharga atas unjuk dalam satuan uang Rupiah yang diterbitkan dengan sistem diskonto oleh Bank Indonesia sebagai pengakuan hutang jangka pendek.
SBI sebagai piranti operasi pasar terbuka digunakan untuk mengendalikan moneter untuk mengendalikan moneter melalui lelang harian. Tujuan bank dan lembaga keuangan lainnya membeli SBI adalah sebagai alternatif kelebihan dananya untuk memeperoleh pendapatan, dan apabila memerlukan dana maka SBI dapat dijual kepada lembaga lain atau Bank Indonesia.

\section{Surat Berharga Pasar Uang (SBPU)}

SBPU adalah surat-surat berharga berjangka pendek yang dapat diperjualbelikan secara diskonto dengan Bank Indonesia atau lembaga diskonto yang ditunjuk oleh BI. SBPU berfungsi sebagi piranti pasar uang dan juga merupakan instrumen operasi pasar terbuka dalam rangka ekspansi moneter oleh Bank Indonesia dengan menetapkan tingkat diskonto SBPU. Ditinjau dari jenis transaksi dan warkatnya, SBPU dapat dibagi sebagai berikut: 
a. Surat Sanggup (aksep/promes), dapat berupa:

- Surat sanggup yang diterbitkan oleh nasabah dalam rangka penerimaan kredit dari bank untuk membiayai kegiatan tertentu.

- Surat sanggup yang diterbitkan oleh bank dalam rangka pinjaman antar bank.

b. Surat Wesel, dapat berupa:

- Surat wesel yang ditarik oleh suatu pihak dan diaksep oleh pihak lain dalam rangka transaksi tertentu. Penarik dan atau tertarik adalah nasabah bank.

- Surat wesel yang ditarik oleh nasabah bank dan diaksep oleh bank dalam rangka pemebrian kredit untuk membiayai kegiatan tertentu.

\section{Call Money}

Call Money merupakan salah satu sarana penting untuk mendorong pengembangan pasar uang. Pasar uang antarbank pada dasarnya adalah kegiatan pinjam meminjam dana antara satu bank dengan bank lainnya untuk jangka waktu pendek.

\subsection{Divisi Treasuri}

Setiap Bank pasti memiliki unit kerja yang mengelola dana, biasanya dilakukan oleh suatu Divisi atau urusan atau Biro yang bertanggung jawab langsung kepada Direksi, unit kerja ini biasanya disebut Divisi, yaitu "Divisi Treasuri" atau Divisi Treasuri dan Dana", sebutan ini bergantung pada kebijakan manajemen bank yang bersangkutan tetapi memiliki tugas dan tanggungjawab serta fungsi yang sama, yaitu mengelola likuiditas dalam rangka optimalisasi pendapatan dan menjaga kepercayaan masyarakat terhadap operasional bank (Riyadi, 2006).

\subsection{Risiko Bank}

Menurut Tampubolon (2004) Risiko Bank dapat didefinisikan sebagai kombinasi 
dari tingkat kemungkinan sebuah peristiwa terjadi disertai konsekuensi (dampak) dari peristiwa tersebut pada Bank. Setiap kegiatan mengandung potensi sebuah peristiwa terjadi atau tidak terjadi, dengan konsekuensi/dampak yang memberi peluang untuk untung (upside) atau mengancam sebuah kesuksesan (downside).

Peraturan Bank Indonesia No. 11/25/PBI/2009 - Perubahan atas PBI No. 5/8/PBI/2003 tentang Penerapan Manajemen Risiko bagi Bank Umum, Bank Umum Konvensional wajib menerapkan Manajemen Risiko yang mencakup 8 risiko, yaitu risiko kredit, risiko pasar, risiko likuiditas, risiko operasional, risiko hukum, risiko reputasi, risiko stratejik, dan risiko kepatuhan. Sementara itu, Bank Umum Syariah wajib menerapkan Manajemen Risiko paling kurang untuk 4 jenis risiko, sebagaimana diatur dalam pengaturan sebelumnya untuk Bank yang tidak memiliki ukuran dan kompleksitas usaha yang tinggi, yaitu risiko kredit, risiko pasar, risiko likuiditas dan risiko operasional.

Untuk mempermudah integrasi antara Manajemen Risiko dan Tingkat Kesehatan Bank, peringkat risiko dikategorikan menjadi 5 peringkat, yaitu 1 (Low), 2 (Low to Moderate), 3 (Moderate), 4 (Moderate to High), dan 5 (High).

Basel II bertujuan meningkatkan keamanan dan kesehatan sistem keuangan, dengan menitikberatkan pada perhitungan permodalan yang berbasis risiko, supervisory review process, dan market discipline. Hal ini untuk memastikan bahwa framework Basel II dapat mengikuti perubahan yang terjadi di pasar maupun perkembanganperkembangan dalam manajemen risiko.

\subsection{Manajemen Risiko}

Manajemen risiko adalah cara-cara yang digunakan manajemen untuk menangani berbagai permasalahan yang 
disebabkan oleh adanya risiko (Kountur, 2004).

$$
\text { Menurut Djohanputro (2008), }
$$

Manajemen risiko korporat terintegrasi, atau

\section{ERM (Enterprise Risk Management)} merupakan proses terstruktur dan sistematis dalam mengidentifikasi, mengukur, memetakan, mengembangkan alternatif penanganan risiko, dan dalam memonitor dan mengendalikan implementasi penanganan risiko.

Proses manajemen risiko meliputi tahapan sebagai berikut:

\section{Mengidentifikasi Risiko}

Risiko merupakan peristiwa yang menghambat pencapaian tujuan perusahaan. Seluruh risiko yang mungkin terjadi dan berdampak negatif bagi perusahaan secara signifikan harus terlebih dahulu diidentifikasi.

Menurut Djohanputro (2008), pada dasarnya, identifikasi risiko dapat dilakukan dengan menggunakan salah satu dari keempat metode berikut, atau bisa juga digunakan secara bersama-sama supaya saling melengkapi.

a. Metode 1: analisis data historis, prinsip ini menggunakan berbagai informasi atau data mengenai segala sesuatu yang pernah terjadi baik data primer maupun data sekunder.

b.Metode 2: pengamatan dan survey, bila tidak tersedia data historis, maka dapat langsung melakukan investigasi, pengamatan atau survey, on the spot.

c. Metode 3: pengacuan (benchmarking), metode ini diterapkan untuk melengkapi identifikasi risiko menggunakan metode 1 dan 2 di atas.

d.Metode 4: pendapat ahli, apabila kesulitan menggunakan ketiga metode yang dijelaskan di atas karena ketidaktersediaan data, maka masih memiliki pilihan lain yaitu bertanya kepada ahlinya. 
11. Menganalisis Risiko

Setelah seluruh risiko diidentifikasi, maka dilakukan pengukuran tingkat kemungkinan dan dampak risiko. Pengukuran risiko dilakukan setelah mempertimbangkan pengendalian risiko yang ada. Pengukuran risiko dilakukan mengunakan kriteria pengukuran risiko secara kualitatif, semi kuantitatif, atau kuantitatif tergantung pada ketersediaan data tingkat kejadian peristiwa dan dampak kerugian yang ditimbulkannya.

Menurut Kountur (2004), untuk mengetahui berapa besar kemungkinan terjadinya risiko dengan memakai metode pengukuran kemungkinan risiko seperti metode Poisson, Binomial, nilai standar (zscore) dan metode Aproksimasi.

- Metode Poisson digunakan bila memenuhi kriteria sebagai berikut:

a. Ada data historis tentang kejadian serupa sebelumnya.
b.Datanya dalam bentuk diskrit (terpisah).

c. Ada periode waktu ke depan yang ditetapkan.

- Metode binomial digunakan apabila memenuhi kriteria sebagai berikut:

a. Ada data historis tentang peristiwa yang terjadi pada suatu lokasi.

b.Datanya dalam bentuk diskrit (terpisah).

c.Diketahui sesuai sesuai dengan data historis ada probabilitas berhasil dan gagal.

- Metode nilai standar (z-score) digunakan apabila memenuhi kriteria sebagai berikut:

a. Ada data historis.

b. Data dalam bentuk kontinyu

- Metode aproksimasi merupakan kirakira karena informasi yang diperoleh merupakan perkiraan atau aproksimasi. Metode ini digunakan untuk memperkirakan kemungkinan dan 
dampak. Pengumpulan informasi pada metode ini dapat dilakukan dengan salah satu dari tiga cara yaitu: pendapat ahli (expert opinion), konsensus (concencus) dan delphy.

Djohanputro (2008), pengukuran risiko dampak risiko terbagi atas empat (4) cara yaitu:

- Notional, menentukan batas atas (upper bound) besarnya nilai yang menghadapi risiko.

- Sensitivitas, mengukur penyimpangan variabel target sebagai akibat pergerakan satu unit variabel pasar.

- Volatilitas, mengukur variasi sekitar rata-rata atau ekspektasi variabel target, baik variasi positif maupun negatif.

- Penyimpangan bawah, mengukur penyimpangan negatif dari variabel target; pengukuran ini ditunjukkan oleh kasus terburuk (worst case). Metode ini digunakan peneliti untuk mengukur kerugian maksimum yang bisa terjadi dari suatu aset atau investasi selama periode tertentu dengan tingkat kemungkinan tertentu.

\section{Mengevaluasi Risiko}

Setelah risiko diukur tingkat kemungkinan dan dampaknya, maka disusunlah urutan prioritas risiko mulai dari risiko dengan tingkat risiko tertinggi sampai dengan terendah.

Risiko yang tidak termasuk dalam risiko yang dapat diterima atau ditoleransi merupakan risiko yang menjadi prioritas untuk segera ditangani. Setelah diketahui besarnya tingkat risiko dan prioritas risiko, maka perlu disusun peta risiko.

\section{Menangani Risiko}

Risiko yang tidak dapat diterima/ ditoleransi segera dibuatkan rencana tindakan untuk meminalkan kemungkinan atau dampak terjadinya risiko dan personil yang bertanggung jawab untuk melaksanakan rencana tindakan. 
14. Memantau Risiko

Perubahan kondisi internal dan eksternal perusahaan menimbulkan risiko baru bagi perusahaan, mengubah tingkat kemungkinan atau dampak terjadinya risiko, dan cara penanganan risikonya. Sehingga setiap risiko yang teridentifikasi masuk dalam Register Risiko dan Peta Risiko perlu dipantau perubahannya.

15. Mengkomunikasikan Risiko

Setiap tahapan kegiatan identifikasi, analisis, evaluasi, dan penanganan risiko dikomunikasikan atau dilaporkan kepada pihak yang berkepentingan terhadap aktivitas bisnis yang dilakukan perusahaan untuk memastikan bahwa tujuan manajemen risiko dapat tercapai sesuai dengan keinginan pihak yang berkepentingan.

\section{5}

Risiko

Operasional

dan

\section{Standardized Approach (SA)}

Risiko operasional adalah semua risiko yang tidak masuk pada kelompok risiko keuangan. Risiko operasional disebabkan oleh faktor manusia, alam, dan teknologi. ( Kountur, 2004).

Tahapan perhitungan risiko operasional dengan Standardized Approach. a. Membagi aktivitas dalam 8 jenis bisnis yaitu: Corporate finance, Trading and sales, Retail banking, Commercial banking, Payment and settlement, Agency service, Asset management, dan Retail brokerage.

Berdasarkan committee basel (basel capital accord I) perhitungan nilai rata-rata standardised approach (SA) selalu dihitung tiga tahun terakhir, dan dapat dirumuskan sebagai berikut: 
$K_{S A}=\frac{\left\{\operatorname{Max}\left[\sum_{i=1}^{n}\left(G I_{i} * \beta_{i}\right), 0\right]\right\}}{3}$

Dimana;

$\mathrm{K}_{\mathrm{SA}}=$ pembebanan modal risiko

operasional menurut metode SA

$\mathrm{GI}_{\mathrm{i}}=$ nilai laba kotor untuk masing-masing

lini bisnis dalam satu tahun untuk jangka

tiga tahun

$\boldsymbol{\beta}_{i=}$ nilai beta (suatu konstanta) yang telah ditetapkan oleh Basel untuk tiap lini bisnis

b.Menggunakan pendapatan kotor (gross income) dari tiap jenis bisnis digunakan sebagai indikator risiko operasional atas masing-masing bisnis. Dasar perhitungan SA dirumuskan dalam consultative document committee Basel on Banking Supervision.

\subsection{Kerangka Teoritis}

Setiap kegiatan dibagian pasar uang (money market) di divisi Treasury mengandung risiko. Oleh sebab itu penulis berusaha untuk mengidentifikasi profil risiko
- risiko apa saja yang mempengaruhi kegiatan pasar uang (money market) tersebut. Pada Gambar 1. dapat dilihat kerangka berpikir dari penelitian ini. 


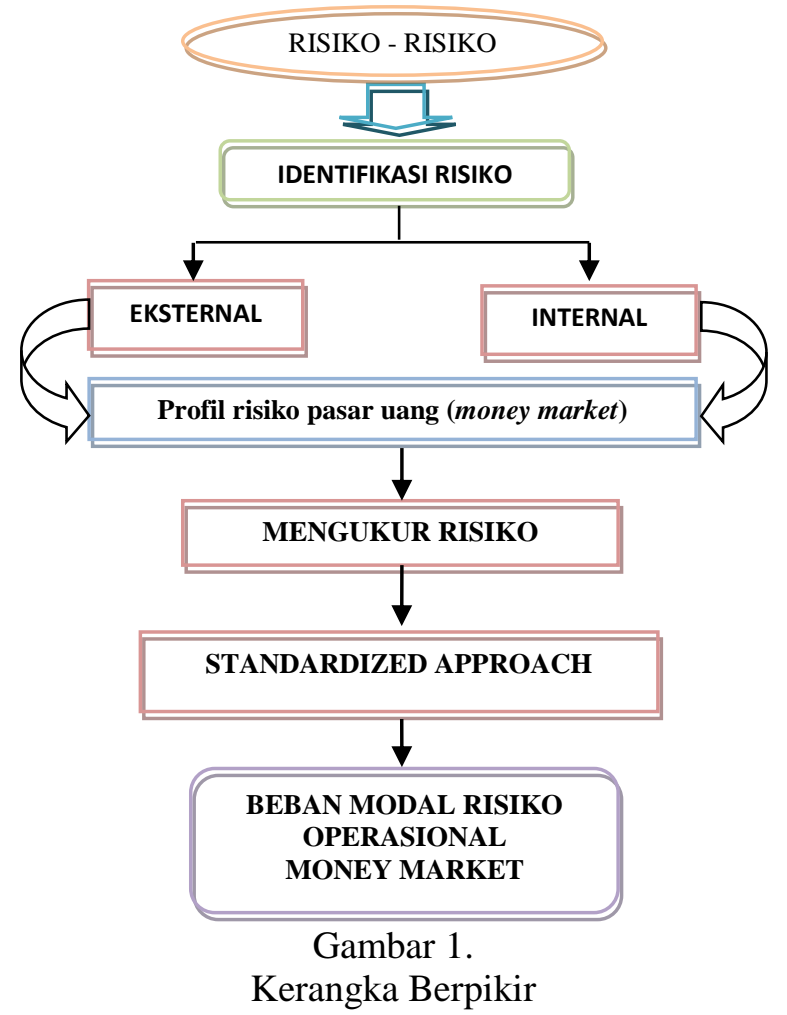

\subsection{Ruang Lingkup Pembahasan}

Ruang lingkup pembahasan dari penelitian ini adalah risiko operasional pada bagian pasar uang (money market). Keterbatasan penelitian terdapat pada data dampak risiko atau kerugian yang diakibatkan risiko tersebut belum didokumentasi dengan baik, oleh sebab itu metode pengamatan langsung dan benchmarking digunakan dalam penelitian ini. Pengukuran operasional dilakukan dengan menggunakan pendekatan standardized approach (SA).

\section{METODOLOGI PENELITIAN}

\subsection{Jenis Penelitian}

Penelitian ini dilakukan dengan pendekatan deskriptif dan analisa kuantitatif menggunakan data primer dan data sekunder 
yang berasal dari perusahaan. Penelitian ini merupakan studi kasus manajemen risiko pada bagian Money Market di Divisi Treasuri PT. Bank MNC Internasional.

\subsection{Metode Pengumpulan Data}

Data penelitian akan diambil dari 2 (dua) sumber, yaitu:

16. Data primer, yang diperoleh dari hasil wawancara dengan beberapa pihak kunci (key person) dari manajemen bank dan serta dari beberapa pendapat ahli dari Treasury.

17. Data sekunder, yang diperoleh baik dari sumber internal perusahaan (data primer) berupa laporan keuangan, laporan kegiatan operasional, dan lain-lainnya. Sedangkan sumber eksternal seperti laporan keuangan lain, laporan Bank Indonesia, analisis pasar, jurnal-jurnal ilmiah dan lain-lainnya.

\subsection{Teknik Analisis dan Penyajian data}

\subsubsection{Teknik Analisis Data}

Penelitian ini menggunakan variabel-variabel yang harus dianalisis dengan teknik analisis kualitatif dan kuantitatif. Pengolahan data kuantitatif ini dibantu dengan program komputer, yaitu program Microsoft Excel. Selanjutnya teknik analisis yang digunakan adalah teknik analisis kualitatif, yaitu memahami, menaksirkan, dan menjelaskan hasil yang diperoleh dalam analisis kualitatif penelitian ini.

\subsubsection{Penyajian Data}

Dalam rangka mempermudah membaca hasil analisis data, penulis akan menyajikan data dalam bentuk tabel, grafik, diagram dan gambar dari hasil analisa. 


\section{HASIL DAN PEMBAHASAN}

\subsection{Profil Risiko Operasional}

Risiko operasional perlu mendapat perhatian penting, karena mayoritas terjadinya kejahatan perbankan karena operasional di perbankan tidak dijalankan dengan baik. Strategic Indonesia mencatat, dalam kuartal I 2011 telah terjadi sembilan kasus pembobolan bank di berbagai industri perbankan. Hal itu bukan hanya soal penipuan (fraud), tetapi lemahnya pengawasan internal control bank terhadap sumberdaya manusia juga menjadi titik celah kejahatan perbankan.

$$
\text { Basel committee on banking }
$$
supervision telah membobot risiko bisnis berdasarkan business line di perbankan (Gambar 2.). Ada terdapat 8 aktivitas bisnis yaitu corporate finance, trading sales, retail banking, commercial banking, payment and settlement, retail brokerage dan asset management. Treasury termasuk ke dalam aktivitas trading and sales dengan bobot risiko antara 15 hingga 23 persen.

\begin{tabular}{lc}
\hline \multicolumn{1}{c}{ Business Line } & Range $(\mathrm{S})$ \\
\hline Corporate Finance & $8-12$ \\
Trasing and Sples & $15-2 \mathrm{~J}$ \\
Retail Banking & $17-25$ \\
Commercial Banking & $13-20$ \\
Payment and Settiement & $12-18$ \\
Retail Broderage & $6-9$ \\
Asset Manapement & $3-12$ \\
\hline Total & $80-120$ \\
\hline
\end{tabular}

The broad bands have an average value which corresponds to $100 \%$

Sumber : Basel committee on banking supervision, 2001

Gambar 2.

Tabel Bobot Risiko Bisnis Line dalam Perbankan

Risiko operasional yang dapat tersebut meliputi: proses Internal, kesalahan timbul diakibatkan kegiatan Divisi Treasuri manusia, kegagalan sistem dan problem 
eksternal. Risiko operasional karena proses internal disebabkan oleh adanya pelanggaran prosedur dan ketentuan.

Kesalahan manusia terjadi karena petugas operasional tidak menjalankan proses operasional dengan baik. Kegagalan pada sistem terjadi karena sistem tidak sistem yang dikembangkan tidak mendukung proses berjalan dengan baik. Risiko operasional dari problem eksternal terjadi di luar kemampuan atau kontrol Divisi Treasuri.

Risiko operasional terbesar pada kontrak money market adalah tidak membuat deal slip money market dan lambatnya proses transaksi system treasuri yang masih manual sehingga melalui ketentuan jam (cut off time). Tidak dibuatnya deal slip transaksi mengakibatkan transaksi antar bank tidak dijalankan, sehingga gagal penyelesaian (settlement fail) dan gagal secara pembukuan.
Dari transaksi kontrak pasar uang (money market) dapat identifikasi risiko operasional sebanyak 40 risiko. Daftar risiko operasional pada transaksi kontrak pasar uang (Money Market) penyebabnya dapat dibagi menjadi internal dan eksternal.

Penyebab risiko yang berasal dari internal sebagai berikut:

1.Tidak mengecek posisi likuiditas sebelumnya pada money market desk.

Apabila money market dealer tidak melakukan pengecekan posisi likuiditas, maka akan berdampak pada posisi bank. Jika posisi kurang disebut short, sedangkan jika posisi berlebih disebut long. Hal ini sangat berbahaya apabila posisi kurang dalam hal pemenuhan Giro Wajib Minimun (GWM) yang ditetapkan oleh Bank Indonesia sebesar 6.5 persen dari dana pihak ketiga. 
2.Salah mengumpulkan informasi pasar, sehingga data analisa tidak cukup untuk trading.

Money market dealer yang tidak cukup informasi mengenai kondisi dan arah pergerakan pasar, akan menyebabkan kerugian bagi bank. Apabila arah market bahwa akan ada penurunan tingkat bunga, apabila dana berlebih tidak ditempatkan maka akan ada kerugian langsung sebesar penurunan rate tersebut.

3. Salah memprediksi pergerakan suku bunga (interest) bank.

Money market dealer selalu dihadapkan pada penentuan posisi bank, dimana setiap bulannya Bank Indonesia mengadakan Rapat Dewan Gubernur (RDG) untuk menentukan suku bunga acuan (BI Rate). Apabila salah menentukan posisi bank akan merugikan bank dari sisi bunga (interest). Misalnya jika Bank MNC tidak memperkirakan akan ada penurunan suku bunga acuan, maka selisih antara suku bunga acuan yang lama dengan suku bunga yang baru merupakan kerugian dari Bank.

4.Tidak melakukan pengecekan fasilitas (line) interbank.

Setiap counterparty bank diberikan fasilitas (limit) interbank yang boleh pada penempatan dana. Apabila melebihi limit berarti melanggar ketentuan internal bank itu sendiri. Setiap kebijakan fasilitas (limit) interbank harus dipatuhi dealer dalam melakukan transaksi pasar uang.

5.Salah menquote rate money market pada broker.

Money market dealer jika memberikan rate baik kepada counterparty atau broker lebih rendah dari harga pasar akan menyebabkan kerugian bunga (interest) pada penempatan dana bank. Misalnya rate di pasar adalah 4.15\%, namun yang diquote adalah $3.15 \%$, maka kerugian $1 \%$ langsung dialami oleh Bank MNC. 
6. Tidak melakukan dealing money market.

Setiap hari dealer menghitung posisi bank baik posisi kurang atau posisi lebih. Jika money market dealer tidak melakukan dealing maka posisi bank menjadi tidak seimbang (square). Ketika bank dalam posisi long, maka Bank mengalami idle money, sedangkan ketika Bank dalam posisi short maka Bank tidak dapat memenuhi kebutuhan GWM dari Bank Indonesia.

7.Tidak melakukan konfirmasi counterparty kalau deal done.

Hal ini akan menyebabkan posisi bank tidak seimbang (square), disebabkan transaksi seperti tidak pernah dilakukan. Jika posisi bank tidak seimbang, maka akan terjadi kemungkinan kekurangan (short) dana atau kelebihan dana (idle money) di Bank MNC.

8. Tidak membuat deal slip Money Market. Jika tidak dibuat deal slip, maka transaksi pasar uang (money market) tidak dapat berjalan. Pihak setelmen juga tidak dapat melaksanakan transaksi yang sudah dilakukan oleh dealer.

9.Deal slip tercecer/hilang.

Jika deal slip tercecer atau hilang, maka transaksi tidak dapat berjalan dan dibukukan dengan baik, sehingga posisi bank menjadi tidak seimbang. Selain itu penyerahan dana (settlement) tidak dilakukan.

10. Tidak mendistribusikan deal slip ke bagian terkait (Back office).

Hal ini menyebabkan transaksi tidak dapat berjalan. Selain itu penyerahan dana (settlement) tidak dilakukan.

11. Salah membuat deal slip (Value date, Maturity, Nominal, Nostro salah).

Hal ini menyebabkan transaksi salah dalam penyelesaian transaksi (settlement). Dapat juga menyebabkan posisi bank tidak seimbang atau klaim dari pihak counterparty. 
12. Tidak membuat blotter money market.

Money market dealer tidak mengetahui transaksi apa saja yang telah dilakukan. Dapat menyebabkan posisi bank salah dan kelebihan limit counterparty pada saat transaksi. Ada juga kemungkinan sudah deal transaksi dua kali.

\section{Blotter money market tercecer.}

Money market dealer tidak mengetahui transaksi yang telah dilakukan. Dapat menyebabkan posisi bank salah dan kelebihan limit counterparty pada saat transaksi.

14. Dealer sakit.

Hal ini menyebabkan bank tidak dapat menjalankan proses transaksi pasar uang (money market) treasury dengan baik. Posisi bank juga bisa tidak diketahui apakah kurang atau lebih.

15. Dealer salah menghitung posisi GWM (IDR atau valas). hal ini dapat menyebabkan kekurangan GWM IDR atau valas dan mendapat sanksi dari Bank Indonesia sebagai regulator kebijakan moneter.

16. Salah dalam pembuatan laporan likuiditas.

Hal ini bisa mendapat surat teguran dari Bank Indonesia. Bank Indonesia akan melakukan pengecekan laporan Bank MNC dalam periode harian, mingguan, bulanan dan tahunan.

17. Dealer tidak mengecek Sistem Kliring Nasional Bank Indonesia (Lupa). Dapat menyebabkan kekurangan dana dan transaksi nasabah tidak berjalan. Dapat juga merusak nama baik Bank karena teledor dalam penyediaan dana.

18. Dealer salah menginput incoming/outgoing RTGS.

Money market dealer tidak mengetahui posisi likuiditas bank yang sebenarnya apakah kurang atau lebih. 
19. Dealer salah memberikan suku bunga kepada nasabah.

Hal ini dapat menyebabkan kerugian secara langsung pada bank. Kerugian yang ditimbulkan adalah bunga (interest).

20. Transaksi melebihi limit Dealer.

Money market dealer melebihi wewenang yang dimilikinya. Dengan demikian dealer melanggar ketentuan internal dari Bank.

21. Sistem treasuri mayoritas masih manual, menyebabkan lambatnya proses transaksi (Cut off time).

Transaksi yang lambat dijalankan dapat menyebabkan gagal dalam penyerahan (gagal settle), juga terlambat dalam pelaporan ke Bank Indonesia.

22. Kegagalan sistem treasuri (OPICS error).

Hal ini menyebabkan transaksi tidak dapat berjalan. Pembukuan dari transaksi tidak dapat dilakukan, sehingga tidak mencerminkan posisi Bank yang benar.
Hal ini menyebabkan terlambatnya pengiriman laporan ke Bank Indonesia. Apabila terdapat bisa mendapat surat teguran dan sanksi biaya dari Bank Indonesia.

24. Mesin printer Reuters rusak.

Hal ini menyebabkan money market dealer tidak dapat mengeprint transaksi yang telah dilakukan. Transaksi tidak dapat diserahkan kepada bagian setelment.

25. Komputer kerja mati.

Money market dealer tidak dapat mengerjakan tugasnya. Posisi bank menjadi tidak diketahui apakah dalam posisi kurang (short) atau lebih (long).

26. Jaringan internet (chatting) terputus.

Hal ini menyebabkan tidak dapat berkomunikasi dengan broker dan counterparty.

\section{Deal slip habis.}

Jika tidak dibuat deal slip, maka transaksi tidak dapat berjalan. Transaksi tidak bisa

23. Jaringan LHBU BI terputus. 
diteruskan ke bagian setelmen untuk dapat dijalankan.

28. Token BI ETP hilang/tercecer.

Hal ini dapat menyebabkan bank tidak dapat mengikuti lelang yang dilaksanakan oleh Bank Indonesia. Posisi bank juga dapat terganggu karena tidak dapat melakukan penempatan ke Bank Indonesia.

\section{Dealer disuspen oleh BI.}

Hal ini akan menyebabkan risiko reputasi bagi bank, karena dealer tidak boleh lagi melakukan transaksi pasar uang (money market).

Penyebab risiko yang berasal dari eksternal sebagai berikut:

30. Laporan Limit Counterparty yang belum update oleh credit admin.

Hal ini menyebabkan money market dealer tidak mengetahui limit counterparty. Dealer dapat salah melakukan penempatan (placement) ke counterparty.
31. Terjadinya bencana alam misalnya gempa bumi, kebakaran dan banjir.

Hal ini menyebabkan kerugian fisik bagi bank. Seluruh aktivitas terganggu dan tidak dapat dilaksanakan.

32. Terjadinya pencurian atau perampokan fasilitas treasuri.

Hal ini menyebabkan kerugian fisik bagi bank. Seluruh aktivitas terganggu dan tidak dapat dilaksanakan.

33. Terjadinya pemadaman listrik oleh PLN.

Hal ini menyebabkan transaksi tidak dapat dijalankan. Seluruh aktivitas terganggu dan tidak dapat dilaksanakan.

34. Pembatalan transaksi oleh counterparty.

Hal ini menyebabkan posisi bank menjadi tidak seimbang (square). Jika posisi lebih dan melakukan penempatan dana, dapat menyebabkan kerugian bunga (interest). Namun jika posisi kurang, dapat 
menyebabkan tidak terpenuhinya kebutuhan GWM bank.

35. Mesin scan faxmile rusak.

Hal ini menyebabkan transaksi tidak dapat dijalankan ke bagian back office. Proses transaksi menjadi lambat untuk dilakukan, karena harus menunggu petugas office boy untuk mengantar dokumen transaksi.

36. Jaringan telpon (IPC) mati oleh jaringan TELKOM.

Hal ini dapat menyebabkan tidak dapat beroperasinya informasi dari broker dan tidak dapat berkomunikasi dengan pihak luar atau counterparty. Komunikasi juga menjadi terganggu apabila ada cabang bank ingin melakukan konfirmasi dana masuk atau keluar.

37. Jaringan Sistem Kliring Nasional Bank Indonesia (SKNBI) terputus.

Sistem oleh Bank Indonesia yang berfungsi untuk memonitor dana masuk (incoming) dan keluar (outgoing) warkat di bank. Sistem ini juga memastikan agar seluruh kliring kredit maupun debet nasabah dapat berjalan dengan baik.

38. Jaringan RTGS terputus.

Sistem oleh Bank Indonesia yang berfungsi untuk memonitor dana masuk dan keluar dari bank. Hal ini dapat menyebabkan posisi bank tidak diketahui apakah kurang (short) atau lebih (long).

39. Jaringan $\mathrm{S} 4$ terputus.

Sistem oleh Bank Indonesia yang berguna dalam memonitor surat berharga. Transaksi surat berharga dapat dilihat pada sistem S4, apabila error maka penyelesaian transaksi surat berharga tidak dapat dilakukan.

40. Jaringan BI-ETP (Electronic Trading Platform) terputus.

Sistem oleh Bank Indonesia yang berguna untuk mengikuti lelang yang diselenggarakan oleh Bank Indonesia. Posisi bank dapat terganggu karena tidak dapat mengikuti lelang yang dilakukan oleh Bank Indonesia. 


\subsection{Pengukuran Risiko Operasional}

(Operational Risk)

Pembebanan modal risiko

operasional menurut metode SA pada penelitian ini dihitung dalam jangka waktu tiga tahun. Oleh sebab itu, pembebanan modal risiko operasional pada Bank MNC Internasional, Tbk menurut metode standardized approach dihitung untuk jangka waktu empat tahun yaitu tahun 2014, tahun 2015, dan tahun 2016. Penulis berasumsi bahwa jangka waktu tiga tahun tersebut dapat menggambarkan berapa modal risiko operasional yang akan dihadapi oleh Divisi Treasuri pada Bank MNC
Internasional, Tbk dan sesuai dengan metode SA.

Divisi treasuri menurut Basel committee on banking supervision masuk ke dalam lini bisnis Trading and Sales dengan kisaran nilai beta adalah $15-23$ persen dan modal regulasi agregat adalah 20 persen. Hal ini juga sesuai dengan bobot penilaian risiko operasional yang ditetapkan oleh manajemen Bank MNC yaitu 19 persen. Hal ini menunjukkan manajemen menetapkan level antara rendah dan level tinggi dari yang ditetapkan kisaran beta Basel.

Berikut Tabel 1. menunjukkan gross income divisi treasuri pada tahun 2014-2016.

Tabel 1.

Gross Income Divisi Treasuri Tahun 2014-2016

\begin{tabular}{||c||c||}
\hline Tahun & Gross income (IDR) \\
\hline \hline $\mathbf{2 0 1 4}$ & $\mathbf{1 1 0 , 1 5 1 , 8 1 1 , 5 1 9 . 2 6}$ \\
\hline \hline $\mathbf{2 0 1 5}$ & $\mathbf{1 8 3 , 5 4 0 , 1 1 7 , 2 8 3 . 3 6}$ \\
\hline \hline $\mathbf{2 0 1 6}$ & $\mathbf{1 6 5 , 0 7 2 , 9 1 0 , 1 8 4 . 8 2}$ \\
\hline \hline TOTAL & $458,764,838,987.44$ \\
\hline
\end{tabular}

Maka perhitungan risiko operasional

adalah sebagai berikut:

$K_{S A}=\frac{\left\{\operatorname{Max}\left[\sum_{i=1}^{n}\left(G I_{i} * \beta_{i}\right), 0\right]\right\}}{3}$
$\mathrm{K}_{\mathrm{SA}}=\left(19 \% *\right.$ Gross-income $\mathrm{e}^{2014}+(19 \% *$ Gross income $\left.^{2015}\right)+\left(19 \% *\right.$ Gross-income $\left.e^{2016}\right): 3$

$\mathrm{K}_{\mathrm{SA}}=\underline{19 \% * 458.764 .838 .987 .44}$

$\mathrm{K}_{\mathrm{SA}}=\mathrm{Rp} \cdot 29,055,106,469 \cdot 20$ 


\section{KESIMPULAN DAN SARAN}

\subsection{Kesimpulan}

Berikut kesimpulan yang didapat dari penelitian ini :

1. Review pada kondisi pasar dan isu-isu perbankan serta wawancara dengan narasumber, maka dapat diketahui bahwa profil risiko yang dihadapi Treasuri di PT. Bank MNC Internasional, Tbk salah satunya adalah risiko operasional pada bagian pasar uang (money market). Hasil identifikasi profil risiko terhadap dari bagian pasar uang (money market) terdapat sebanyak 40 risiko. Risiko yang berasal dari internal terdapat 29 risiko, sedangkan penyebab risiko operasional yang berasal dari eksternal terdapat 11 risiko.

2.Dampak risiko operasional pada bagian pasar uang (money market) dengan menggunakan metode Standardized
Approach (SA) sebesar Rp. 29,055,106,469.20. Hal ini menggambarkan modal risiko operasional yang harus dihadapi oleh PT. Bank MNC Internasional, Tbk.

\subsection{Saran}

Saran-saran yang dapat diberikan dari penelitian ini adalah sebagai berikut :

1.PT. Bank MNC Internasional, Tbk hendaknya dapat menerapkan entreprise risk management (ERM) di PT. Bank MNC Internasional, Tbk.

2.Membuat sistem yang menyimpan dan mendokumentasikan seluruh risiko-risiko yang terjadi di PT. Bank MNC Internasional, Tbk. 


\section{DAFTAR PUSTAKA}

Bank Indonesia. 2009. Manajemen Risiko Likuiditas Untuk Perbankan Indonesia. Direktorat Penelitian dan Pengaturan Perbankan. Jakarta.

Bank for International Settlement .2001.” Basel committee on banking supervision”. Supporting Document to the New Basel Capital Accord. Issued for comment by 31 May 2001.

Djohanputro, Bramantyo. 2008. Manajemen Risiko korporat. Penerbit PPM, Februari $2008 . \quad$ Seri Manajemen Keuangan No. 13. Jakarta.

Kasmir.2012. Manajemen Perbankan. Edisi Revisi. Penerbit PT. Raja Pers. Jakarta.

Kountur, Ronny. 2004. Manajemen Risiko operasional: memahami cara mengelola risiko operasional perusahaan. Penerbit PPM, Jakarta.

Tampubolon, Robert. 2004. Risk Management. Pendekatan Kualitatif untuk Bank Komersial. Penerbit PT. Elex Media Komputindo, Kelompok KOMPAS - GRAMEDIA, Jakarta.

Riyadi, Selamet. 2006. Banking assets and liability management. Edisi Ketiga. Lembaga Penerbit Fakultas Ekonomi Universitas Indonesia. Jakarta.

http://www.bi.go.id/web/id/Peraturan/Arsip+Peraturan/

http://www.bi.go.id/id/moneter/operasi/penjelasan/Contents/Proses_om.aspx 